\title{
The efficiency of growing large meat chickens of various crosses in cage batteries
}

\author{
Rustam Abdulkhalikov ${ }^{1, *}$, and Victor Malorodov ${ }^{2}$ \\ ${ }^{1}$ Kabardino-Balkarian State Agricultural University named after V.M.Kokov, Lenin Avenue, 1V, 360030 \\ Nalchik, Russia \\ ${ }^{2}$ FSBEI RSAU - Moscow Timiryazev Agricultural Academy, str. Timiryazevskaya 49, 127550 Moscow, \\ Russia
}

\begin{abstract}
The article presents the results of a comprehensive assessment of the possibility of producing large meat chickens of domestic and foreign crosses with the cage method of growing, considering the separation by gender. The highest broiler productivity index was 213 units, which is by 27 units higher than when growing broilers of a foreign cross. The content of histidine is significantly higher in the meat of broilers of the domestic cross (by $0.50 \mathrm{~g}$ in the muscles of cockerels and by $0.54 \mathrm{~g}$ in the muscles of hens). It was found that it is advisable to produce large meat chickens using the domestic SK-Rus 613 cross for deep processing of individual parts of carcasses. The results are confirmed by the zootechnical efficiency of broiler production, the biological usefulness of the muscle composition and meat qualities, as well as the taste and aroma properties of meat products.
\end{abstract}

\section{Introduction}

The intensification of broiler meat production contributes to the expansion of the range of poultry products and determines the need to enhance technology, considering the increasing pre-slaughter poultry live weight. Growing large meat chickens causes the need to implement deep processing of individual parts of carcasses. Broiler meat industrial production is aimed at increasing the uniformity of the poultry live weight, which is ensured by technological standards for growing $[4,8,10,18]$. The stocking density of poultry, calculated depending on the final average live weight, is one of the important indicators.

Currently, the technological standards providing for the rearing of large meat chickens on deep litter have been developed and tested $[22,25]$. However, the possibility of producing broiler meat for deep processing with the cage method of growing poultry, depending on the cross of poultry at a standard stocking density, has not been studied in detail $[1,2,12]$. In most cases, birds were observed to have breast folds, in connection with which studies on the assessment of the use of crosses of domestic and foreign selection for the production of large meat chickens in cages are relevant. It is important to take consider the latest advances in

\footnotetext{
${ }^{*}$ Corresponding author: rustam742008@mail.ru
} 
breeding, feeding and broiler growing technology [5-7, 9, 11, 13-17, 19-21, 23, 24]. The optimum period for raising the number of gender-segregated broilers for the production of large meat chickens has not been identified as well.

The purpose of the research is to determine the efficiency of the cage production of large meat chickens of various crosses, considering the division by gender, and to assess the biochemical composition and quality of broiler meat.

\section{Materials and methods}

The study was performed at the poultry farm of OOO Veles-Agro (Kabardino-Balkarian Republic, Prokhladnensky district), which is the epizootic-free state. Broilers of crosses SKRus 613 and Ross-308 were grown up to 49 days old (cockerels) and up to 56 days old (hens) in a poultry house using the cage method pursuant to the scheme presented in Table 1 . Chickens were divided by gender at day old age. The number of birds in groups 1 and 2 was 110 birds each, in groups 3 and $4-120$ birds each. The total initial livestock in the experiment is 460 chickens. The stocking density per cockerel was $410 \mathrm{~cm}^{2}$; per chicken $-370 \mathrm{~cm}^{2}$; load on 1 nipple - 9 animals, feeding area $-2.3 \mathrm{~cm}$ per 1 animal. Air exchange in the halls was provided by a supply and exhaust ventilation system operating on the principle of negative pressure with end exhaust ventilation.

Table 1. Experiment scheme.

\begin{tabular}{|c|c|c|c|c|}
\hline \multirow{2}{*}{ Indicator } & \multicolumn{4}{|c|}{ Group } \\
\cline { 2 - 5 } & $\mathbf{1}$ & $\mathbf{2}$ & $\mathbf{3}$ & $\mathbf{4}$ \\
\hline Broiler cross & SK-Rus 61 3 & Ross-308 & SK-Rus 61 3 & Ross-308 \\
\hline Chicken gender & $\hat{\sigma}$ & $\hat{0}$ & $q$ & $q$ \\
\hline
\end{tabular}

The samples of breast muscle tissue were taken from three clinically healthy broilers with an equal average pre-slaughter body weight (separately for cockerels and hens) in order to study the amino acid composition of broiler meat. Slaughter and anatomical cutting were performed to assess the meat qualities of broilers. The experiment conditions comply with the requirements of the recommendations "On measures on further enhancement of the organizational forms of work using experimental animals " (Order of the USSR Ministry of Health No. 755 dated August 12, 1977) and "The Guide for Care and Use of Laboratory Animals" (National Academy Press, Washington, DC, 1996). All efforts to minimize bird suffering and reduce the number of birds under study were made. The juiciness of the meat was assessed using the Grau-Hamm method; tenderness or roughness of meat was assessed using a consistometer; weight loss of carcasses before and after cooking was assessed as well. The tasting assessment was performed in accordance with the methodological recommendations of VNITIP.

\section{Results and discussion}

The average pre-slaughter live weight of meat chickens significantly differs in all groups, regardless of gender. In addition, broilers of domestic cross-country reliably exceed broilers of foreign cross-breed in average live weight by $166 \mathrm{~g}$ (cockerels) and by $118 \mathrm{~g}$ (hens). The broilers of group 1 exceeded the average daily gain of broilers in group 2 by $3.4 \mathrm{~g}$, at the same time, among the hens, the difference was $2.1 \mathrm{~g}$ in favor of the domestic cross. The preservation in groups was in the range of 95.4-96.9\% with the highest indicator in group 3. The feed consumption per $1 \mathrm{~kg}$ of live weight gain was lower in the cross of domestic selection among cockerels by $0.21 \mathrm{~kg}$; among hens it was $0.28 \mathrm{~kg}$ in comparison with foreign cross of broilers. 
There was a tendency for hens to consume more feed than cockerels, which is associated with a lower intensity of weight gain. In group 1, the highest broiler productivity index was obtained - 213 units, which is 27-102 units higher than in groups 2-4 (Table 2).

Table 2. Broiler farming results.

\begin{tabular}{|c|c|c|c|c|}
\hline \multirow{2}{*}{ Indicator } & \multicolumn{3}{|c|}{ Group } \\
\cline { 2 - 5 } & $\mathbf{1}$ & $\mathbf{2}$ & $\mathbf{3}$ & $\mathbf{4}$ \\
\hline Average pre-slaughter live weight, g & $2852.0 \pm 50.4 \mathrm{a}$ & $2686.0 \pm 49.4 \mathrm{~b}$ & $2342.0 \pm 45.9 \mathrm{c}$ & $2224.0 \pm 36.7 \mathrm{~d}$ \\
\hline Daily gain, g & 57.4 & 54.0 & 41.1 & 39.0 \\
\hline Preservation, \% & 95.4 & 95.8 & 96.9 & 96.8 \\
\hline Feed costs per 1 kg gain, kg & 2.61 & 2.82 & 3.18 & 3.46 \\
\hline Broiler productivity index, units & 213 & 186 & 127 & 111 \\
\hline
\end{tabular}

Note: the difference between the mean values in the groups within the indicator, indicated by different letters, is significant at $\mathrm{P} \geq 0.95$.

As a result of the analysis of the amino acid composition of broiler muscles, no regular differences were found in the quantitative content of nonessential, semi-nonessential and essential amino acids, depending on the cross (Table 3). Nevertheless, it was noted that the level of histidine, which is an essential amino acid for children, was significantly higher in the meat of domestic broilers (by $0.50 \mathrm{~g}$ in the muscles of cockerels and by $0.54 \mathrm{~g}$ in the muscles of hens). Histidine is a precursor in the biosynthesis of histamine that promotes the growth and repair of human tissues. In the case of severe deficiency of this amino acid, speech impairments and decreased mental activity are possible.

Additionally, the fatty acid composition of broiler meat has been studied. It was revealed that in terms of the total content of fatty acids, the meat of chickens of the Ross-308 cross was superior to that of the SK-Rus 613 chicken. The level of fatty acids in the meat of broilers of foreign breeding was noted in the range of 27.7-29.9 g per $100 \mathrm{~g}$, while the same indicator in the meat of domestic chickens was 24.3-25.3 g per $100 \mathrm{~g}$. The advantage can be explained by the increased content of oleic acid, which is not indispensable for humans and is not considered when determining the biological value of the fatty acid composition of broiler meat [3]. The high biological value of lipid compounds in broilers is provided by polyunsaturated fatty acids (linoleic and linolenic), which are easily assimilated by the human body and are irreplaceable. In terms of the PUFA amount, the meat of poultry of domestic cross is 15.1 $19.2 \%$ higher than the meat of broilers of foreign cross.

Table 3. Amino acid composition of broiler muscles (g) per $100 \mathrm{~g}$.

\begin{tabular}{|c|c|c|c|c|}
\hline \multirow{2}{*}{ Amino acid } & \multicolumn{4}{|c|}{ Group } \\
\cline { 2 - 5 } & $\mathbf{1}$ & $\mathbf{2}$ & $\mathbf{3}$ & $\mathbf{4}$ \\
\hline Valin & 1.02 & 0.98 & 1.04 & 0.98 \\
\hline Isoleucine & 0.96 & 1.00 & 0.98 & 0.98 \\
\hline Leucine & 1.65 & 1.76 & 1.57 & 1.75 \\
\hline Lysine & 1.86 & 1.86 & 1.94 & 1.87 \\
\hline Methionine & 0.64 & 0.63 & 0.75 & 0.63 \\
\hline Trenin & 1.02 & 0.95 & 1.02 & 1.03 \\
\hline Phenylalanine & 1.03 & 0.94 & 1.04 & 0.86 \\
\hline Alanine & 1.12 & 1.08 & 1.16 & 1.19 \\
\hline Arginine & 1.62 & 1.49 & 1.55 & 1.38 \\
\hline Aspartic acid & 2.03 & 1.20 & 2.08 & 1.86 \\
\hline Histidine & 1.48 & 0.98 & 1.53 & 0.99 \\
\hline Glutamic & 3.31 & 3.20 & 3.48 & 3.41 \\
\hline Proline & 0.99 & 0.99 & 0.99 & 0.94 \\
\hline Tyrosine & 0.59 & 0.69 & 0.61 & 0.56 \\
\hline Serine & 0.85 & 0.75 & 0.87 & 0.85 \\
\hline Cystine & 0.20 & 0.18 & 0.22 & 0.18 \\
\hline
\end{tabular}


The meat qualities of broilers are presented in table 4. Domestic cross broilers outnumber the foreign cross broilers in terms of the gutted carcass weight by $144.5 \mathrm{~g}$ (cockerels) and by $112.5 \mathrm{~g}$ (chicken). A similar trend can be seen in terms of the muscle mass ration to the gutted carcass mass. There were no significant differences between cockerels and hens of different crosses in terms of the weight of bones from the weight of the gutted carcass and the weight of inedible parts from the pre-slaughter live weight. Significant superiority was revealed in terms of the weight of edible parts relatively to the pre-slaughter live weight of the bird. Thus, the cockerels of the domestic cross had an advantage of $145.6 \mathrm{~g}$, the hens - by $117.9 \mathrm{~g}$, in comparison with the foreign cross of broilers. The ratio of edible parts to inedible parts in the domestic poultry is generally higher.

Table 4. Broiler meat quality.

\begin{tabular}{|c|c|c|c|c|}
\hline \multirow{2}{*}{ Indicator } & \multicolumn{4}{|c|}{ Group } \\
\cline { 2 - 5 } & $\mathbf{1}$ & $\mathbf{2}$ & $\mathbf{3}$ & $\mathbf{4}$ \\
\hline Gutted carcass weight, g & 2067.7 & 1923.2 & 1658.1 & 1545.6 \\
\hline $\begin{array}{c}\text { Muscle mass relatively to } \\
\text { the gutted carcass mass, g }\end{array}$ & 1497.0 & 1386.6 & 1193.8 & 1105.1 \\
\hline $\begin{array}{c}\text { Bone weight relatively to } \\
\text { the gutted carcass weight }\end{array}$ & 322.6 & 321.2 & 253.7 & 255.0 \\
\hline $\begin{array}{c}\text { Weight of edible parts } \\
\text { relatively to pre-slaughter } \\
\text { live weight, g }\end{array}$ & 1726.5 & 1580.9 & 1396.1 & 1278.2 \\
\hline $\begin{array}{c}\text { Mass of inedible parts } \\
\text { relatively to pre-slaughter } \\
\text { live weight, g }\end{array}$ & 1125.5 & 1105.1 & 945.9 & 945.8 \\
\hline $\begin{array}{c}\text { The ratio of edible parts to } \\
\text { inedible parts }\end{array}$ & 1.53 & 1.43 & 1.48 & 1.35 \\
\hline
\end{tabular}

The main physical indicators of the meat qualities of broilers are shown in table 5. Judging by the juiciness of the meat of the pectoral and leg muscles, there is a tendency of superiority in the studied indicator of hens over cockerels, regardless of the cross. In general, it should be noted that large meat chickens of domestic cross had a slight advantage in terms of meat juiciness. The tenderness of the meat of the pectoral and leg muscles is significantly lower in broilers of foreign cross, both among cockerels and chickens.

Table 5. Physical indicators of the meat qualities of broilers.

\begin{tabular}{|c|c|c|c|c|}
\hline \multirow{2}{*}{ Indicator } & \multicolumn{4}{|c|}{ Group } \\
\cline { 2 - 5 } & $\mathbf{1}$ & $\mathbf{2}$ & $\mathbf{3}$ & $\mathbf{4}$ \\
\hline Juiciness of meat, \%: & & & & \\
pectoral muscles & 59.41 & 58.75 & 60.04 & 59.42 \\
\cline { 2 - 5 } leg muscles & 59.90 & 58.98 & 60.21 & 59.93 \\
\hline Tenderness of meat, mm: & & & & \\
pectoral muscles & 4.1 & 33.6 & 4.31 & 34.2 \\
leg muscles & 53.87 & 6.40 & 4.02 & 0.92 \\
\hline
\end{tabular}

The results of meat moisture loss after cooking and organoleptic evaluation of broiler meat are shown in Table 6. It was found that when cooking and roasting meat of domestic crossbreed chickens, the moisture loss is lower in comparison with the foreign cross of broilers. Judging by all indicators of the organoleptic assessment, the meat of chickens of groups 1 and 3 is slightly superior to those of groups 2 and 4, which allows us to conclude about the greatest taste value of meat obtained from poultry of domestic selection. 
Table 6. Moisture loss and organoleptic evaluation of broiler meat.

\begin{tabular}{|c|c|c|c|c|}
\hline \multirow{2}{*}{ Indicator } & \multicolumn{4}{|c|}{ Group } \\
\cline { 2 - 5 } & 1 & 2 & 3 & 4 \\
\hline $\begin{array}{c}\text { Loss of moisture in meat, \%: } \\
\text { when cooking } \\
\text { when roasting }\end{array}$ & 24.2 & 25.7 & 24.5 & 25.1 \\
\cline { 2 - 5 } & 33.1 & 35.1 & 33.7 & 34.8 \\
\hline $\begin{array}{c}\text { Organoleptic assessment, score: } \\
\text { bouillon } \\
\text { cooked meat } \\
\text { grilled meat }\end{array}$ & 5.00 & 4.94 & 5.00 & 4.95 \\
\cline { 2 - 5 } & 4.97 & 4.87 & 4.98 & 4.90 \\
\cline { 2 - 5 } & 5.00 & 4.92 & 5.00 & 4.93 \\
\hline
\end{tabular}

\section{Conclusions}

The studies performed indicate the feasibility of production using the domestic cross SK-Rus 613 for cage growing of broilers in the form of large meat chickens for deep processing of individual parts of carcasses. The results are confirmed by the zootechnical efficiency of broiler production, the biological usefulness of the muscle composition and meat qualities, as well as the taste and aroma properties of meat products.

\section{References}

1. V. S. Buyarov, I. P. Saleeva, Ye. A. Buyarova, Bulletin of the Oryol State Agrarian University, 2(17), 54 (2009)

2. V. S. Buyarov, Ye. A. Buyarova, V. A. Borodin, Animal Science, 9, 24 (2003)

3. I. V. Zhuravlev, T. G. Aydinyan, V. I. Fisinin, D. A. Davtyan, Agricultural Biology, 6, 66 (1999)

4. A. Osmanyan, L. Bakaeva, Yu. Plaksin et al Growing large broilers in cages, Poultry farming, 4(11) (1993)

5. A. Osmanyan, I. Saleeva, V. Malorodov, R. Gaifullin, Chief zootechnician, 7, 52 (2019)

6. A. K. Osmanyan, V. V. Malorodov, Poultry and poultry products, 1, 13 (2021)

7. A. Osmanyan, R. Mahdavi, V. Malorodov, Chief zootechnician, 3, 50 (2018)

8. A. K. Osmanyan, Abstract of thesis ... of Doctor of Agricultural Sciences (1998)

9. A. K. Osmanyan, V. V. Malorodov, N. G. Cherepanova, I. P. Saleyeva, Poultry farming, 12, 42 (2020)

10. Technology of growing large meat chickens for deep processing of meat (1994)

11. V. I. Fisinin, Bulletin of the Russian Academy of Sciences, 85(9), 785 (2015)

12. V. I. Fisinin, T. A. Stollyar, V. S. Buyarov, Bulletin of the Oryol State Agrarian University, 1(4), 6 (2007)

13. V. I. Fisinin, World and Russian poultry farming: realities and challenges of the future (2019)

14. V. I. Fisinin, L. I. Tuchemsky, J. V. Yemanuylova, Agricultural Biology, 40(2), 39 (2005)

15. V. I. Fisinin, Bulletin of the Russian Academy of Sciences, 87(4), 333 (2017)

16. V. I. Fisinin, K. V. Zlochevskaya, Agricultural Biology, 5, 3 (1984)

17. V. Z. Khamitova, A. K. Osmanyan, R. A. Yerigina et al. Zootechnics, 9, 15 (2019) 
18. V. Z. Khamitova, A. A. Gerasimov, I. V. Cheredov, A. K. Osmanyan, Poultry farming, 12, 13 (2012)

19. V. Z. Khamitova, A. K. Osmanyan, V. V. Malorodov, Poultry farming 1, 22 (2021)

20. G. A. Bobyleva, Poultry \& Chikenproducts, 3, 12 (2010)

21. V. I. Ficinine, A. K Ocmanyan, R. Mahdavi, I. A. Egorov, Animal Nutrition, 3(3), 258 (2017)

22. Poultry, 5,16 (1994)

23. R. Mahdavi, A. K Osmanyan, V. I. Fisinin et al, Journal of Animal Physiology and Animal Nutrition, 102(5), 1266 (2018)

24. A. K Osmanyan, R. Mahdavi, S. Ghazi Harsini et al., Amino Acids, 50(2), 353 (2018)

25. T. A. Stollar, V. S. Lukashenko, A. N. Tishenko, Pat. 2057459 Russian Federation, IPC

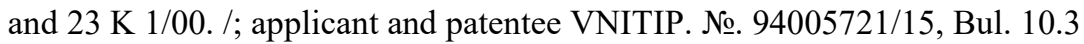

